\title{
A New Approach to Collecting Children's Statements Concerning Their Prenatal and Perinatal Memories
}

\author{
Ohkado Masayuki* \\ Professor, Graduate School of Global Humanics, Chubu University, Japan \& Visiting Professor, Division of Perceptual Studies, University of Virginia, USA
}

Received: May 11, 2018; Published: May 17, 2018

*Corresponding author: Masayuki Ohkado, Graduate School of Global Humanics, Chubu University, 1200 Matsumoto-cho Kasugai-shi Aichi-ken, 4878501, Japan

\begin{abstract}
The pioneering research by Dr. Ian Stevenson of children claiming to have past-life memories has been developed by other researchers to include children with other types of "anomalous" memories such as life-between-life, womb, or birth memories. These memories are called prenatal and perinatal memories here. A potential problem of these studies is that the records of these memories typically are often made long after the cases came to be known by the investigators, so that we cannot completely exclude the possibility that these memories are imposed or inspired by family members of the children. This can be a serious weakness of the evidential value of these data in view of the fact that the suggestibility of pre-school children has been experimentally proven to be high. To overcome this weakness, I would like to propose a method of recording children's initial remarks of prenatal and perinatal memories without any intervention by investigators.
\end{abstract}

Keywords: Children's Prenatal and Perinatal Memory; Methodology; Past-Life Memory; Life-Between-Life Memory; Womb Memory; Birth Memory

\section{Introduction}

\section{Stevenson's Research and Its Development}

In 1960s, Dr. Ian Stevenson started to investigate cases of children claiming to remember past-life memories, and showed that the cases from various regions have a similar pattern: At a young age, children start talking about past-life memories. Many of them give detailed information about their past-life personalities and often they are identified. Sometimes, the families of the past-life personalities accept the children as their dead family members. However, by the time the children become adults, their past-life memories often fade away[1-9].

Ms. Poonam Sharma and Dr. Jim Tucker focused on life-between-life memories ["intermission memories" in their terminology] of children with past-life memories and pointed out the similarities (and also differences) between such memories and memories of another realm talked about by near-death experiencers, and emphasized that there are common characteristics observed in these two types of memories[10]. The present author and Dr. Akira Ikegawa showed that children with life-between-life memories are not subgroups of children with past-life memories and that there are significant similarities between life-between-life memories of children with past-life memories and those of children without them, so that, irrespective of whether they have past-life memories or not, children with life-between-life memories warrant further investigation [11].

Other researchers have pointed out that a significant number of young children talk about memories in the womb and at birth, and that sometimes such memories contain verifiable elements [12-16]. So, womb memories and birth memories share some important features with past-life memories and life-between-life memories: The mechanisms of how children come to possess such "memories" are unknown within the currently predominant view of the human cognitive system, but they are "real" in the sense that possessors of these memories believe that the events they remember did take place and sometimes they are verified. The present author conducted a large-scale internet-based survey and revealed that there are a number of important relations among these four types of memories (past-life, life-between-life, womb, and birth memories): Possessors of these memories often overlap; that is, children may speak of more than one type. Across the four types of memories, children begin to talk about the memories at around 3, but as they grow older, they talk about these memories less and less, and in most cases they stop talking about them by the age of 12. Again, across the four types of memories, children are most likely to talk about these memories at bedtime, then, while or after taking a bath, and then, while eating [17]. 


\section{Problems and a Proposal to Solve Them}

Stevenson's research on children's past-life memories has been criticized from a number of angles and some of them are also pertinent to the extended version of investigating the four types of memories [18-21]. Especially important are the following two:

I. Questioning children can be especially difficult because of their high suggestibility.

II. Investigations typically took place a long time after a child started talking about relevant memories, so the investigated cases are based on parental memories instead of first-hand stories from the child.

As for the first problem, there are some studies showing that adults who had claimed to have past-life memories when they were young were not different in suggestibility from those who hadn't [22-24]. So, one possible way to overcome the suggestibility issue is to utilize the same or similar psychological tests when participants become adults. As for the second problem, researchers, especially Dr. Ian Stevenson, adopted a very rigorous method of interviewing as many witnesses as possible and interviewing the same witnesses a number of times to overcome the problem. Neither solution, however, is easily implemented. The best possible solution to these problems would be to record all the behaviors and speeches of a child from the birth and analyze the obtained "big data" systematically as done by Dr. Deb Roy of the MIT Media Laboratory [25]. Unfortunately, the Deb Roy type investigation is not feasible in most cases, and one of the second best solutions would be to record a child's talking about these memories at the inception stage in natural settings without the intervention by the investigators. The procedure proposed by the present author is as follows:

I. Participants are young children (ideally between 2 and 5) who have never talked about nor been asked about any of the four types of memories:

i. past-life memories

ii. life-between-life memories

iii. womb memories

iv. birth memories.

Mothers of such children are handed an IC recorder or alternatively use their own recording device such as smartphones, and are asked to record a conversation with their children. In the conversation, a mother will ask a child if he/she remembers when he/she was in her tummy (= womb memories).

II. If the child talks about such memories, the mother will ask if he/she remembers before he/she comes to her tummy (= life-between-life memories). If the child also talks about such memories, the mother will ask if he/she remembers before he/ she comes to the place where he/she was before they came to her tummy (= past-life memories). Finally, the child will be asked if he/she remembers when he/she was born (birth memories).
III. Mothers are instructed to ask these questions at bedtime in view of the fact that children are most likely to talk about prenatal and perinatal memories at bedtime [17]. Mothers are also instructed to ask their child as if they are asking them about an incident he/she had on the day.

IV. If the child talks about one or more of such memories, the mother will ask the same questions at least for two more nights (to see if there are any developments or discrepancies in the child's story). If the child's story develops in a way in which no discrepancies are observed, the mother will keep on asking (once a week, then, once a month) for a year. If the child's story involves discrepancies and the mother feels that he/she is talking about fantasies, the recording period will end. Also, if the child does not talk about any of such memories for the maximum of five nights or if the mother feels the child is unwilling to talk about such memories, the recording period will end.

V. The recorded data are transcribed for analyses.

VI. For cases in which a child's story is rich in content, interviews with the child and the mother are conducted.

VII. If memories of a child are specific enough, they are examined if they have verifiable elements, which includes interviews with witnesses.

One might claim that this approach does not overcome the issue of suggestibility because children's response might be affected by their mothers' "suggestion." I would argue that we can judge from the audio data whether children's remarks are spontaneous or affected by their mothers' suggestion. In any case, as stated before, this is the second-best approach, a compromise.

\section{A Preliminary Report of the Investigation}

Table 1: Response of the Participants Concerning the Four Types of Memories.

\begin{tabular}{|c|c|c|c|c|c|c|c|}
\hline $\begin{array}{c}\text { Partici- } \\
\text { pant No. }\end{array}$ & Sex & $\begin{array}{c}\text { Age in } \\
\text { months }\end{array}$ & $\begin{array}{c}\text { No. of } \\
\text { Record- } \\
\text { ings }\end{array}$ & $\begin{array}{c}\text { Birth } \\
\text { Mem- } \\
\text { ory }\end{array}$ & $\begin{array}{c}\text { Womb } \\
\text { Mem- } \\
\text { ory }\end{array}$ & $\begin{array}{c}\text { Life-Be- } \\
\text { tween- } \\
\text { Life } \\
\text { Memory }\end{array}$ & $\begin{array}{c}\text { Past- } \\
\text { Life } \\
\text { Mem- } \\
\text { ory }\end{array}$ \\
\hline 1 & F & 56 & 2 & & & & \\
\hline 2 & F & 85 & 2 & & & & \\
\hline 3 & M & 78 & 3 & & & & \\
\hline 4 & F & 29 & 2 & & & & \\
\hline 5 & M & 71 & 2 & & & & \\
\hline 6 & M & 78 & 5 & & $\checkmark$ & $\checkmark$ & \\
\hline 7 & F & 47 & 1 & & & $\checkmark$ & \\
\hline 8 & M & 70 & 5 & & $\checkmark$ & $\checkmark$ & \\
\hline 9 & F & 35 & 7 & & $\checkmark$ & $\checkmark$ & \\
\hline 10 & F & 60 & 5 & & $\checkmark$ & \\
\hline 11 & F & 62 & 3 & & $\checkmark$ & \\
\hline 12 & F & 54 & 4 & $\checkmark$ & $\checkmark$ & $\checkmark$ & \\
\hline
\end{tabular}

The investigation with the above mentioned procedure started in April, 2017 in Japan. Participants were recruited via SNS (Facebook) and acquaintances. (The present author works as a volunteer at a kindergarten and has a number of acquaintances having young 
children.) An unexpected obstacle was to find participants: Many of the mothers I contacted had already asked their children about their prenatal and perinatal memories and I was forced to relax the condition to include those who had asked their children about the memories once or twice, but got no or little positive response from them. The high percentages of mothers who had already asked their children about prenatal and perinatal memories is no doubt due to the works by Dr. Akira Ikegawa, who has popularized children's prenatal and perinatal memories through books, essays, and lectures for the general public in Japan. This conjecture seems to be supported by the results of the internet-based survey of 10,000 randomly selected women in the country: As many as 7245 $(72.5 \%)$ said that they knew the existence of children who talk about womb memories [17].At present, 12 children participated in the study and the results are summarized in Table 1.

The check marks indicate that the child talks about the particular memories. The number of participants is too small to warrant statistical analyses, but the results of the present investigation appear to show that criticizing this line of research on the basis of children's high suggestibility is not appropriate: Instead of creating a story in response to the mother's "suggestion," children simply say: "I don't remember" if they don't. None of the children talk about any verifiable information so the authenticity of the memories cannot be judged, but their stories did contain elements commonly observed in cases involving verified elements $[11,26,27]$ : They chose their parents (participants 7, 10,11, 12); other "spirits" including God or a god-like figure were with them (participants 7, 8, 9, 10,11,12); they were very small when they were in their mother's womb (like a green pea [participant 7], and like a sesame see [participant 10]); and they were able to see outside when they were in their mothers' womb (participants $7,12)$. The audio data reveal that the way the participants talked about these memories is not like children talking about fantasies and their stories are mostly consistent.

\section{Conclusion}

The present paper proposed a new approach to collecting children's statements concerning their prenatal and perinatal memories. The application of this method is still an initial stage and the results reported here are preliminary, but I hope the present paper has shown that the approach proposed here can overcome the problems of the time lag between children's initial remarks and the start of investigations and those related to children's high suggestibility.

\section{Acknowledgment}

This study was approved by the Chubu University Institutional Review Board (\#260100) and partially supported by Chubu University grant $A$ and the Helene Reeder Memorial Fund for Research into Life After Death. I would like to thank all the participants and their mothers of this study. I am also grateful to Dr. James Matlock for his invaluable comments on an earlier version of this paper. All remaining inadequacies are of course my own.

\section{References}

1. Stevenson I (1960) The Evidence for Survival from Claimed Memories of Former Incarnations. Journal of the American Society for Psychical Research 54: 51-71 and 95-117.

2. Stevenson I (1966) Twenty Cases Suggestive of Reincarnation. New York: American Society for Psychical Research

3. Stevenson I (1975) Cases of the Reincarnation Type I: Ten Cases in India. Charlottesville, VA.: The University Press of Virginia.

4. Stevenson I (1977) Cases of the Reincarnation Type II: Ten Cases in Sri Lanka. Charlottesville, VA.: The University Press of Virginia.

5. Stevenson I (1980) Cases of the Reincarnation Type III: Twelve Cases in Lebanon and Turkey. Charlottesville, VA.: The University Press of Virginia.

6. Stevenson I (1983) Cases of the Reincarnation Type IV: Twelve Cases in Thailand and Burma. Charlottesville, VA The University Press of Virginia.

7. Stevenson I (1997) Reincarnation and Biology: A Contribution to the Etiology of Birthmarks and Birth Defects (2 vols.). London/Westport: Praeger.

8. Stevenson I (2001) Children Who Remember Previous Lives: A Question of Reincarnation, revised edition. Jefferson, McFarland \& Company, London.

9. Stevenson I (2003) European Cases of the Reincarnation Type. Jefferson, NC, McFarland \& Company, London.

10. Sharma P, Tucker JB (2004) Cases of the Reincarnation Type with Memories from the Intermission Between Lives. Journal of Near-Death Studies 23(2): 101-118.

11. Ohkado M, Ikegawa A (2014) Children with Life-Between-Life Memories. Journal of Scientific Exploration 28(3): 477-490.

12. Chamberlain D (1988) Babies Remember Birth. Ballantine Books, New York, USA.

13. Chamberlain D (1998)The Mind of Your Newborn Baby. Berkeley, North Atlantic Books, USA.

14. Ikegawa A (2005) Investigation by Questionnaire Regarding Fetal/Infant Memory in the Womb and/or at Birth. Journal of Prenatal and Perinatal Psychology and Health 20(2): 121-133.

15. Verny T, Kelly J (1981) The Secret Life of the Unborn Child. Dell Publishing, New York, USA.

16. Verny T, Weintraub P (2002) Pre-Parenting: Nurturing Your Child from Conception. Simon \& Schuster, New York, USA.

17. Ohkado M (2015) Children's Birth, Womb, Prelife, and Past-Life Memories: Results of an Internet-Based Survey. Journal of Prenatal and Perinatal Psychology and Health 30(1): 3-16.

18. Carroll RT (2013) Ian Stevenson (1918-2007). The Skeptic's Dictionary. http://skepdic.com/stevenson.html

19. Edwards $P$ (ed.) (1997) Immortality. Prometheus Books, New York, USA.

20. Hritz AC, CE Royer, RK Helm, KA Burd, K Ojeda, et al. (2015) Children's Suggestibility Research: Things to Know Before Interviewing a Child. Anuario de PsicologíaJurídica 25: 3-12.

21. Mills A, SJ Lynn (2000) Past-Life Experiences. Varieties of Anomalous Experience: Examining the Scientific Evidence, ed. by E. Cardena, S. J. Lynn, and SCKrippner. Washington, DC: American Psychological Association: 283-313.

22. Haraldsson E (1997) A psychological comparison between ordinary children and those who claim previous-life memories. Journal of Scientific Exploration 11(3): 323-335. 
23. Haraldsson E (2003) Children who speak of past-life experiences: Is there a psychological explanation? Psychology and Psychotherapy: Theory, Research and Practice 76(1): 55-67.

24. Haraldsson E, Fowler PC, Periyannanpillai V (2000) Psychological characteristics of children who speak of a previous life: A further field study in Sri Lanka. Transcultural Psychiatry 37(4): 525-544.
25. Roy D (2009) New Horizons in the Study of Child Language Acquisition. (Invited Keynote Paper) Proceedings of Interspeech 2009.

26. Tucker JB (2013) Return to Life: Extraordinary Cases of Children Who Remember Past-Lives. New York: St. Martin's.

27. Tucker JB (2016) The Case of James Leininger: An American Case of the Reincarnation Type. Explore 12(3): 200-207.

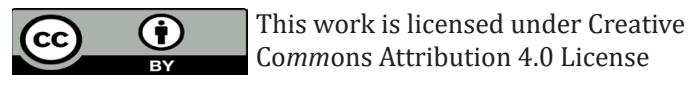

Submission Link: https://biomedres.us/submit-manuscript.php

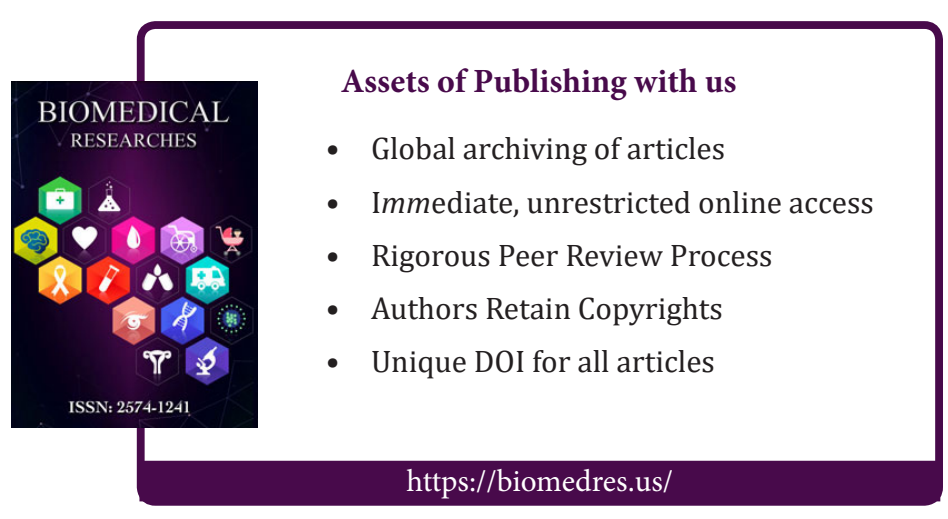

